\title{
Orthologous surface proteins from Mycoplasma hyopneumoniae and Mycoplasma flocculare: in silico comparison and heterologous expression of differential extracellular domains
}

\author{
Carolina Martello ${ }^{*}$, Fernanda Leal, Veridiana Virginio, Luciano Reolon, Irene Schrank, Arnaldo Zaha, \\ Henrique Ferreira
}

From 5th Congress of the Brazilian Biotechnology Society (SBBIOTEC)

Florianópolis, Brazil. 10-14 November 2013

\section{Background}

Mycoplasma hyopneumoniae and Mycoplasma flocculare are two closely related mycoplasma species often found in the porcine respiratory tract[1]. However, M. hyopenumoniae is pathogenic, being the causative agent of enzootic pneumonia, while $M$. flocculare is a commensal bacterium. Enzootic pneumonia is a contagious respiratory disease characterized by chronic cough, growth retardation, low mortality, and a high morbidity. It causes significative economic losses in pig industry worldwide. Some of main interactions between the host and the bacteria are mediated by surface proteins, and a comparison of surface proteins between these two mycoplasmas species can lead to identification of determinants of pathogenicity or commensalism.

\section{Methods}

In this work the deduced amino acid sequences of $M$. hyopneumoniae and $M$. flocculare surface proteins $[1,2]$ were aligned and comparatively analyzed. Comparative analysis was made by sequencing alignments using ClustalW algorithm available in the MEGA 5.05 software package. Orthologous pairs of interest were selected based on the differential presence of amino acid stretches $\geq 5$ residues or regions of significantly reduced homology in comparison to flanking sequences. Topology analyses including predictions of extracellular and transmembrane domains were performed using the TopPred, phobius and TMHMM programs. The

Centro de Biotecnologia, Universidade Federal do Rio Grande do Sul, Porto Alegre, RS, Brazil differential domains of the selected orthologous pairs were amplified by PCR from genomic DNA of the respective species and these amplicons were cloned into the pGEX4T-3 plasmid by in vivo homologous recombination in Escherichia coli $\mathrm{KC} 8$ [3]. The recombinant plasmids were expressed in $E$. coli strains adequate to heterologous expression, and the expressed recombinant polypeptides were purified by affinity chromatography and thrombin cleavage.

\section{Results and conclusions}

A total of 170 putative surface protein sequences with identified orthologs in both M. hyopneumoniae and M. flocculare (MHP and MF, respectively) were analyzed. From this survey, three pairs of orthologs were selected for functional analysis, based on the presence of differential amino acid stretches in predicted extracellular domains. In the first pair (MHP7448_0556 and MF_00306), the M. flocculare protein presents an exclusive 53 aa-long stretch in its $\mathrm{N}$-terminal extracellular end. In the second pair (MHP7448_0094 and MF_00500) less conserved $\mathrm{N}$-terminal sequences (40.5\% identical) are present, in comparison to the rest of the proteins $(80 \%$ identical). And, finally, the third pair (MHP7448_0612 and MF_00357) showed an 114 aa-long stretch with 35\% identity between orthologs, flanked by regions with $70 \%$ $80 \%$ identity. This third pair of orthologs had the differential domains (with $306 \mathrm{bp}$ and $393 \mathrm{bp}$, respectively) cloned and expressed in E. coli. Star and pLysE strains. GST-tagged recombinant polypeptides of $37 \mathrm{kDa}$ and 40 $\mathrm{kDa}$ were expressed and, after purification and cleavage with thrombin, $11.4 \mathrm{kDa}$ and $14.7 \mathrm{kDa}$ polypeptides were 
recovered for MHP7448_0612 and MF_00357, respectively. The differential domains of the other two pairs of selected orthologs will be also cloned and expressed in $E$. coli and all the recombinant polypeptides from $M$. hyopneumoniae and $M$. flocculare produced will be used for immunization of mice, in order to get evidence of potential differences between the immune responses induced by each ortholog.

Published: 1 October 2014

\section{References}

1. Vasconcelos AT, Ferreira HB, Bizarro CV, Bonatto SL, Carvalho MO, Pinto PM, Almeida DF, Almeida LG, Almeida R, Alves-Filho L, Assunção EN, Azevedo VA, Bogo MR, Brigido MM, Brocchi M, Burity HA, Camargo AA, Camargo SS, Carepo MS, Carraro DM, de Mattos Cascardo JC, Castro LA, Cavalcanti G, Chemale G, Collevatti RG, Cunha CW, Dallagiovanna B, Dambrós BP, Dellagostin OA, Falcão C, Fantinatti-Garboggini F, Felipe MS, Fiorentin L, Franco GR, Freitas NS, Frías D, Grangeiro TB, Grisard EC, Guimarães $C T$, Hungria M, Jardim SN, Krieger MA, Laurino JP, Lima LF, Lopes MI, Loreto EL, Madeira HM, Manfio GP, Maranhão AQ, Martinkovics CT, Medeiros SR, Moreira MA, Neiva M, Ramalho-Neto CE, Nicolás MF, Oliveira SC, Paixão RF, Pedrosa FO, Pena SD, Pereira M, Pereira-Ferrari L, Piffer I, Pinto LS, Potrich DP, Salim AC, Santos FR, Schmitt R, Schneider MP, Schrank A, Schrank IS, Schuck AF, Seuanez HN, Silva DW, Silva R, Silva SC, Soares CM, Souza KR, Souza RC, Staats CC, Steffens MB, Teixeira SM, Urmenyi TP, Vainstein MH, Zuccherato LW, Simpson AJ, Zaha A: Swine and poultry pathogens: the complete genome sequences of two strains of Mycoplasma hyopneumoniae and a strain of Mycoplasma synoviae. J Bacteriol 2005, 187(16):5568-5577.

2. Siqueira FM, Thompsom CE, Virginio VG, Gconchoroski T, Reolon L, Almeida LG, da Fonsêca MM, de Souza R, Prosdomici F, Schrank IS, Ferreira $H B$, de Vasconcelos AT, Zaha A: New insights on the biology of swine respiratory tract mycoplasmas from a comparative genome analysis. BMC Genomics 2013, 14(14):175.

3. Parrish JR, Limjindaporn T, Hines JA, Liu J, Liu G, Finley RL: Highthroughput cloning of Campylobacter jejuni ORFs by in vivo recombination in Escherichia coli. J Proteome Res 2004, 3(3):582-586.

doi:10.1186/1753-6561-8-S4-P157

Cite this article as: Martello et al:: Orthologous surface proteins from Mycoplasma hyopneumoniae and Mycoplasma flocculare: in silico comparison and heterologous expression of differential extracellular domains. BMC Proceedings 2014 8(Suppl 4):P157.

\section{Submit your next manuscript to BioMed Central} and take full advantage of:

- Convenient online submission

- Thorough peer review

- No space constraints or color figure charges

- Immediate publication on acceptance

- Inclusion in PubMed, CAS, Scopus and Google Scholar

- Research which is freely available for redistribution

Submit your manuscript at www biomedcentral com/submit
Biomed Central 